\title{
2. The unfinished business of Indigenous citizenship in Australia and New Zealand
}

\author{
Roderic Pitty
}

Australia and New Zealand are cognate societies characterised by a partial, lopsided engagement. There is regular and extensive interaction in the realms of business and the law, so much so that a recent Australian parliamentary report on harmonising legal systems in both countries was promoted in the New Zealand Lawyer under the heading 'moving to a closer union with Australia'. ${ }^{1}$ There is no harmony in sporting contacts between the societies, but these have become a routine, weekly occurrence. Meanwhile, those who see beyond corporate profits and parochialism encourage the creation of a profoundly closer union, based on a mutual awareness of similar problems. Michael Kirby, who served as judge of the Australian High Court from 1996 to 2009, once proposed a two-state solution for New Zealand's inclusion within a Federation of Australasia, but has accepted such 'constitutional matrimony' is politically impossible. He has argued, however, that 'something new, imaginative and different' should be created in the political interchange between Australia and New Zealand in the lead-up to the ANZAC centenary in 2015. He suggests that this trans-Tasman engagement should be a broad and enlightening process, one that is not limited to economics and contributes to an enhanced understanding of how both societies can resolve similar challenges. ${ }^{2}$

One challenging area in which mutual learning between Australia and New Zealand should be enhanced concerns how these states have dealt with Indigenous peoples. The history of colonisation in both countries has been subject to extensive research and some public debate. In both cases, however, government policies towards Indigenous peoples have hardly ever been developed and scrutinised in the light of a critical assessment of the failures of past policies. Instead, political uses of the past in this area have tended to be occasional and opportunistic, influenced by a search for immediate justifications of existing policy rather than by an understanding of historical legacies. Comparative insights rarely intrude into such immediate uses of history, although it is occasionally acknowledged by politicians that public policy failures - for example, in not improving Aboriginal health in Australia-are worse than in comparable societies such as New Zealand. ${ }^{3}$ This predominant mode of the political use of history has reflected mythical traditions of national memory, 
such as the rhetoric of Australia as a land of the 'fair go' ${ }^{4}$ By ignoring comparisons, it has limited the public space for developing policies that would enable Indigenous peoples to achieve a position of genuine equality with respect for cultural difference in Australia and New Zealand.

This chapter reviews examples of the political use of history that concern relations between the State and Indigenous peoples in Australia and New Zealand, arguing that the crucial issue is whether a political use of history constrains or facilitates adequate public policy. First, a framework for analysing how politicians use the past to justify present policies will be considered, focusing on the scope for political distortion of the past. Then the problem of Indigenous exclusion from effective participation in policy making will be outlined, principally with reference to issues of 'unfinished business' regarding recognition of Indigenous rights in Australia. Three Australian examples of the use of history by politicians when discussing Indigenous peoples will be analysed. These are the official apology to the Stolen Generations given by Prime Minister, Kevin Rudd, on 13 February 2008 and speeches by Rudd as Leader of the Opposition and by then Prime Minister, John Howard, on 27 May 2007, on the fortieth anniversary of the 1967 referendum on Aborigines. The tension between these examples will be compared with the impact in New Zealand of the illusory rhetoric of uniform citizenship used in 2004 by Don Brash, leader of the opposition National Party. I aim to show that a comparative understanding of the unfinished business of Indigenous citizenship in Australia and New Zealand would enhance public policy in both states, and help to foster an enabling rather than a constraining use of history by politicians.

\section{Crisis management and political distortion of the past}

In an era of dramatically improved communications technology, expectations about the temporal awareness of policy makers have grown. In 1997, then UN Secretary-General, Kofi Annan, said that 'policy-makers and concerned publics know more about the possible ways in which today's actions or inactions might shape the state of things to come'. He suggested this awareness had partly eroded 'the very distinction between present and future for policy purposes'. ${ }^{5}$ This preoccupation with managing perceptions of the future also affects political uses of the past. One way to examine this is to analyse different dimensions of using the past in political decision making. Concerning the use of historical analogies in crisis management, the three 'continuums' identified by Brändström et al. are particularly useful. These are: 1) whether the past situation is remembered deliberately or spontaneously; 2) whether past events are used cognitively to understand the present or politically to justify a current policy; and 3) whether the impact of a use of history is 'constraining' or 'enabling' - that is, whether the range of relevant policy options assessed is thereby reduced or enlarged. ${ }^{6}$ While all three dimensions are significant, it is most important to consider how 
the third dimension is affected by one or both of the others - that is, why and how a particular historical comparison enhances or diminishes consideration of good policy options.

This analytical framework provides insight into the use of history in a context of crisis by decision makers, who must respond to a novel situation under pressure of immediate time constraints. In such circumstances, the quality of analogical reasoning is most critical. The importance of an appropriate analogical 'filter' or lesson, which helps decision makers to accurately interpret the character of the crisis and see possible pitfalls, can be decisive in enabling a crisis to be resolved, not escalated with catastrophic consequences. ${ }^{7}$ Probably the most important example occurred during the Cuban missile crisis, when US President John F. Kennedy and his brother Robert avoided a cataclysmic surprise attack on Russian missiles in Cuba in favour of a negotiated solution, partly because the case of Pearl Harbor made them realise how illegitimate such an attack would seem, and that it would be likely to provoke a disastrous Russian response. ${ }^{8}$ This episode shows something else, however, about how key decision makers often use history politically. The real process through which the crisis was resolved was kept top secret and was deliberately obscured in order to create the misleading impression that Soviet leader, Nikita Khrushchev, had backed down in the face of American pressure, rather than reached an agreement to withdraw Russian missiles from Cuba in exchange for Kennedy's secret commitment to withdraw US missiles from Turkey, as well as his public commitment not to attempt another invasion of Cuba. ${ }^{9}$

This historic case of crisis management highlights the importance of how politicians can misrepresent their experience of resolving a crisis as history. It also shows how they can use historical analogies as a weapon or a tool for political persuasion. During a crisis, such an opportunist use of history might be 'enabling', in the narrow and 'value-neutral' sense of facilitating the process of decision making. ${ }^{10}$ Crisis management is not, however, a technical procedure. It involves choices between values that have critical consequences, so it is inadequate to study the process of decision making without considering whether a particular decision is defensible in terms of certain values and consequences. Olaf Kleist's analysis of the Tampa crisis (Chapter 5) illustrates this point well. The Howard Government's rhetoric of border protection enabled a speedy, militarised resolution of a manufactured 'crisis', but this rhetoric constrained any proper consideration of an appropriate response to the plight of onshore refugees. Artificial crisis management in that case contributed to a narrowing of policy making.

An important implication of these two cases is that it should not be presumed that the opportunistic use of historical analogies by politicians to persuade audiences should be characterised as 'enabling' - that is, as widening the horizons 
of decision makers. ${ }^{11}$ Indeed, the mystification of the Cuban missile crisis suggests a different hypothesis. One consequence of the misrepresentation of that crisis, as a case of who blinked first, was to accelerate the build-up or vertical proliferation of nuclear weapons. A critic of the Western strategic mind-set that contributed to that outcome has called that mind-set (created before the Cuban missile crisis, but reinforced after it) a 'deterrence dogma', which pervasively constrains sensible policy. ${ }^{12}$ The alternative hypothesis about the opportunistic use of historical analogies can be stated as a general presumption and a limited exception. While this use might occasionally be enabling if it helps to resolve an uncertainty that obstructs the process of policy making, usually good policy will result from a use of history that is based on an appropriate analogical filter or lesson. For a use of history to enable good policy, it must not only facilitate a real (rather than artificial) resolution of a policy problem, it must not create other, larger problems.

\section{Indigenous citizenship as unfinished business}

The claims made by Indigenous peoples in Australia and New Zealand for a distinct yet equal form of citizenship within these states pose major challenges for politicians leading, or aspiring to lead, those states. History is an important aspect of those claims. In Australia, this is reflected in the regular use of the phrase 'unfinished business' to refer to the outstanding agreements that are needed to achieve a national reconciliation. ${ }^{13}$ The need for such agreements has been emphasised by Pat Dodson, the first chair of the Council for Aboriginal Reconciliation during the 1990s. Responding to the Howard Government's intervention in the Northern Territory in 2007, Dodson called again for Australia's 'unfinished business' with Indigenous peoples to be resolved through a 'political settlement', which would become 'a formal symbol of our shared history'. He claimed that, whereas a 'political settlement approach to Indigenous relationships' had been adopted in recent decades in New Zealand and Canada, the reassertion of assimilation by the Howard Government highlighted the 'perennial crises' that have engulfed the Australian nation over its unreconciled relationship with Indigenous peoples. ${ }^{14}$

Such crises reflect the exclusion of many Indigenous people from participation as full citizens, with opportunities to achieve not just formal equality (that is, the same rights as other citizens) but substantive equality (a similar capacity to exercise those rights). The crucial distinction between formal and substantive equality is related to a parallel distinction between what Baubock has called 'nominal and substantial citizenship'. ${ }^{15}$ Nominal citizenship is little more than nationality, or access through a passport to the State's protection beyond its borders. Substantial citizenship is much more important, because it concerns people's capacity to enjoy human rights living within their state. The crises of everyday life for Indigenous people are experienced as an absence of that 
capacity. There is disagreement about how to respond effectively to those crises, yet agreement among Aborigines about the widespread lack of substantial citizenship. Cape York Aboriginal leader Noel Pearson, when diagnosing the problems in his community, used the term 'nominal citizenship' to describe the problem of 'passive welfare' - that is, bureaucratic dependence on a neo-colonial state. He said this had stopped Aborigines from experiencing 'the true meaning of citizenship'. ${ }^{16}$ Pearson's Aboriginal critics, such as Megan Davis, dispute the wisdom of his political actions during the dotage of the Howard Government, but they also argue forcefully that the crises experienced by Indigenous people result from an absence of full citizenship. ${ }^{17}$

This absence is obscured if citizenship is conflated, as it often is in Australia, with a dominant idea of a culturally homogenous nation, not linked to political participation and protecting human rights. David Pearson has noted that conflating citizenship with nationality prevents the creation of new, inclusive forms of citizenship for Indigenous peoples in Australia and New Zealand. ${ }^{18} \mathrm{~A}$ similar conflation has existed in many modern societies, because nominal citizenship has 'generally depended on membership in a national community'. ${ }^{19}$ Maintaining a distinct national identity is, however, made increasingly difficult by global changes, such as the diminishing capacity of states to protect citizens' welfare, greater cultural interchange and more diverse sources of migration. ${ }^{20}$ Reacting to those changes, some politicians in Australia and New Zealand have reasserted ideas of exclusionary citizenship, using the rhetoric of formal equality to deny real cultural differences and the legacies of colonisation. As Paul McHugh has noted, such rhetoric promotes a false dichotomy by proposing a choice between equality for all and difference for some. ${ }^{21}$ Genuine equality, however, requires substantial citizenship, not cultural uniformity. In a society that is structured by Indigenous dispossession, there is a pressing need for what Baubock has called 'differentiated collective rights for socially unequal groups'. He has argued that for Indigenous peoples to really participate in the broader society, 'some rights have to be unequal in order to equalize the worth of citizenship'. ${ }^{22}$

In reality, rights of citizenship within nation-states (and globally) have always been 'deeply differentiated'. ${ }^{23}$ The structure of contemporary societies means that, as in George Orwell's Animal Farm, some people are 'more equal' than others. Rhetoric of formal equality can be used to maintain such a situation. A clear example occurred in 1988 when John Howard, as Leader of the Opposition, responded to Prime Minister Bob Hawke's promise of a treaty with Australian Indigenous peoples by rejecting this as an 'absurd' idea, which 'denies the fact that Aboriginal people have full citizenship rights now'. ${ }^{24}$ In 2000, Howard dismissed a call for a treaty by reducing Indigenous difference to just cultural uniqueness and social disadvantage, thus ignoring the legacies of dispossession. ${ }^{25}$ 
His claim that Aborigines already were full citizens was based on the narrow, legal concept of citizenship as a formal or administrative notion. This has been used as a means of exclusion and disregards the normative concern for achieving substantive equality. ${ }^{26}$ Indigenous people reject this narrow view of citizenship for various reasons. These include the fact that formal citizenship rights do not enable political participation in a context of welfare dependency and the fact that, for first peoples, 'citizenship is not predicated on the same basis' as for everyone else. ${ }^{27}$ In normative terms, citizenship involves 'a political bargain between the individual and the state', so the nature of this bargain will reflect the particular history between these two types of actors. ${ }^{28}$ It will be affected by the fact that Indigenous people identify themselves first with reference to their tribal community, then as individuals within the Australian nation. ${ }^{29}$

The significance of continuing tribal affiliations for understanding the citizenship of Indigenous peoples in Australia has often been underestimated. During the era of assimilation, as a declared aim of government policy, in some states, such as Western Australia, the only way Aborigines could be recognised as citizens was by separating themselves as individuals from their ancestral communities. More broadly, access to nominal Australian citizenship (and potentially to substantial citizenship) was used by the State as a means of control, while it curtailed civil rights and repressed Indigenous political identity. ${ }^{30}$ The experience of the Stolen Generations shows the totalitarian extent of such control. $^{31}$ For some administrators, such as A. O. Neville, the Protector of Aborigines in Western Australia from 1915 until 1940, this was motivated by the genocidal aim of destroying Aborigines as distinct peoples. ${ }^{32}$ Neville's 'long range plan', elaborated at a 1937 conference, was to 'merge' Aborigines 'into our white community' and so ensure that Australians would 'eventually forget that there ever were any Aborigines in Australia'. ${ }^{33}$ This was an example of a powerful official trying to rewrite history and engage in social engineering on a massive scale, with disastrous consequences. The failure of the assimilation policy to produce such amnesia, despite breaking up Aboriginal families, has implications for understanding Indigenous citizenship. ${ }^{34}$ Neville presumed that white citizenship was the measure of Aboriginal equality, just as Howard later did, but Aborigines did not have exactly the same relationship with the State as other Australian citizens. ${ }^{35}$ The Commonwealth Parliament's apology to the Stolen Generations on 13 February 2008 provided an opportunity for a different history of first peoples in Australia to be recognised and understood.

\section{Australia turns a new page: the apology}

The official Apology to Australia's Indigenous Peoples was delivered as the first item of business of the new Parliament elected with the defeat of the Howard Government in November 2007. The apology was widely received positively as part of a process of healing. This was because its text was negotiated with 
Aboriginal leaders of the Stolen Generations, rather than with the Opposition Leader, Brendan Nelson, who rather grudgingly accepted the need for this act of healing, which Howard had denied for more than 10 years. It was also because the rhetoric of the apology spoke about transforming relationships between Indigenous and non-Indigenous peoples, so 'that this new page in the history of our great continent can now be written'. There was a direct link between 'acknowledging the past and laying claim to a future that embraces all Australians', one 'based on mutual respect, mutual resolve and mutual responsibility'. ${ }^{36}$

The apology was presented by Prime Minister Rudd as a response to public demands, based on 'universal human decency', that the Australian nation 'now step forward to right a historical wrong' ${ }^{37}$ He called forth a new and changed Australia, one that could finally 'bring the first two centuries of our settled history to a close, as we begin a new chapter' by embracing 'with pride, admiration and awe these great and ancient cultures we are truly blessed to have among us' ${ }^{38}$ It was this rhetoric of change, linked to an open acknowledgment of the abuses suffered by the Stolen Generations, which helped to make the apology a unifying experience. The radical Aboriginal leader from Brisbane, Sam Watson, who had been sceptical about the timing of the apology, said after hearing it that 'that moment will then close the door on one era in Australian history'. ${ }^{39}$ Rudd started his speech by referring to the need 'to deal with this unfinished business of the nation, to remove a great stain from the nation's soul' ${ }^{40}$ The apology's success depended on an appreciation that healing a divided society required a direct acknowledgment of, and learning from, the past.

Although there was no specific mention of citizenship in the apology or in Rudd's speech, the idea of equality of participation in Australian society was central to the rhetoric of change. The apology envisioned 'a future where all Australians, whatever their origins, are truly equal partners, with equal opportunities and an equal stake in shaping the next chapter in the history of this great country' ${ }^{41}$ It essentially expressed the ideal of substantive, rather than merely formal, equality. As with other official apologies, a central purpose of the Australian apology was 'to change the terms and meanings of membership in a political community' - that is, expectations of how Aborigines and Torres Strait Islanders could participate in Australian society. ${ }^{42}$ Rudd said that the apology was 'aimed at building a bridge between Indigenous and non-Indigenous Australians - a bridge based on a real respect rather than a thinly veiled contempt' ${ }^{43} \mathrm{He}$ emphasised that historical recognition was central to the apology, both by telling the story of a member of the Stolen Generations, Nanna Nungala Fejo, and by calling on Australians to help 'transform the way in which the nation thinks about itself'. 44 
While not discussing the question of genocide, which had been raised in the Bringing Them Home report, Rudd rejected the claim that the forced separation of Aboriginal children had been benevolent. He said the fact that senior officials such as Neville had tried to eliminate Aboriginality must be faced, not ignored. ${ }^{45}$ Apart from lacking an accompanying public education campaign, the main thing missing in his speech was an acknowledgment that compensation for the forced separation of Aboriginal children from their families was legitimate, as recommended by the Bringing Them Home report and accepted for similar practices in Canada. ${ }^{46}$ Rudd acknowledged, however, the cultural and historical differences 'between those who emerged from the Dreamtime a thousand generations ago and those who, like me, came across the seas only yesterday' ${ }^{47}$ He promoted the ideal of a partnership between Indigenous and non-Indigenous Australians as the only decent way to deal with the unfinished business of the past and embrace the future.

As well as the discussion of the suffering of the Stolen Generations, there were two other significant historical references in Rudd's speech. One of these was a general point about the fact that 'most old approaches' have failed to help bridge the appalling gap in life expectancy, educational achievement and employment opportunities between Indigenous and non-Indigenous Australians. Rudd called for 'a new beginning which contains real measures of policy success or failure' and for 'a new partnership' that has 'sufficient flexibility not to insist on a one-size-fits-all approach for each of the hundreds of remote and regional Indigenous communities across the country'. ${ }^{48}$ The key reference to a new partnership with Indigenous peoples suggests a new process of policy making, informed by what Pat Dodson has called a renewed 'formal dialogue' between the government and Indigenous peoples. Dodson has stressed that 'the crisis in Aboriginal Australia' cannot be resolved 'solely by intervention by government authority', especially as implemented by a 'dysfunctional bureaucratic machinery'. He argues that 'partnerships cannot be constructed by legislation or by schemes that involve the coercive use of public funds', but only 'through a process of engagement based on mutual respect, trust and a deep understanding and commitment to agreed objectives' ${ }^{49}$ While such a process is compatible with Rudd's rhetoric in his apology speech, he did not clearly espouse it. Instead, he proposed merely a 'joint policy commission' involving the Opposition, which has since foundered. ${ }^{50}$ No Aboriginal representative institution has been created to replace the Aboriginal and Torres Strait Islander Commission abolished in 2004, and the lack of a formal process of dialogue with Indigenous representatives remains a major cause of unaccountable government policy.

The other historical reference Rudd made was to the 'unfulfilled spirit of the 1967 referendum'. He said there was a need for politicians to 'move beyond our infantile bickering, our point-scoring and our mindlessly partisan politics and 
elevate this one core area of national responsibility to a rare position beyond the partisan divide'. He linked this objective to a new partnership with Indigenous peoples, which puts 'an absolute premium on respect, cooperation and mutual responsibility as the guiding principles' of cooperative action. ${ }^{51}$ This accurately summarises the purpose of the 1967 referendum, which was seen by those who campaigned for its success for more than a decade as designed to achieve substantive equality for Aborigines and Torres Strait Islanders. ${ }^{52}$ The referendum was not an attempt to achieve nominal citizenship for Indigenous people, but an attempt to create a constitutional basis that could facilitate efforts towards equalising substantial citizenship, by giving the Federal Government authority to create special laws for Aborigines when needed by them. There is much debate about the constitutional significance of the referendum, but importantly, Rudd referred to its unfulfilled spirit as a guiding principle of a cooperative partnership with Indigenous peoples, which requires a completely new process of policy making.

\section{Australia spurns a new page: the intervention}

The optimism created by the apology contrasts markedly with the widespread confusion and disappointment surrounding the Rudd Government's continuation of the Howard Government's ad hoc manner of intervening in the lives of many remote Aboriginal communities in the Northern Territory. While the new government has made some changes, such as to reinstate permits required for most outsiders to access Aboriginal land and to restore a community training program, the paternalistic nature of the intervention has been maintained. The new government ignored calls for the intervention to be urgently reviewed from Mick Dodson, the Oceania representative to the UN Permanent Forum on Indigenous Issues, and Tom Calma, the Aboriginal and Torres Strait Islander Social Justice Commissioner. ${ }^{53}$ These and other critics called for the intervention to be transformed by negotiating with communities about how to improve basic government services such as education, health, housing and policing. Calma has highlighted 'the danger of unilateral action' by governments, which 'is reflected in processes that treat Indigenous peoples as passive recipients of policy rather than active agents for change'. ${ }^{54}$ He noted that justifications for the ad hoc intervention relied on the appeal and seductive charm of embracing new approaches and breaking from the past', without being informed by any historical analysis of past government failures. ${ }^{55}$ Professor Larissa Behrendt made a similar criticism, pointing out that service delivery should never require that people surrender their rights, particularly when the people who are losing their rights are defined only by race. ${ }^{56}$

How has the Rudd Government come to adopt a paternalistic form of intervention that is not only by definition racist, because it suspends the Racial Discrimination Act 1975, but which is clearly inconsistent with the spirit of partnership in 
which the apology was offered and received? There could be various reasons, but ignorance of what a suitable policy would be is not one of them. In his apology speech, Rudd explicitly endorsed the need for 'flexible, tailored, local approaches to achieve commonly agreed national objectives that lie at the core of our proposed new partnership'. ${ }^{57}$ This is what critics of the paternalistic nature of the NT intervention have been calling for, yet the government has been slow to signal its willingness to create partnership in practice. To understand why, it is useful to examine what Howard and Rudd said in the lead-up to the intervention. The intervention was announced at a press conference on 21 June 2007- ostensibly as a response to the failure of the NT Government to act on a report about child abuse in Aboriginal communities. The background to this policy fiasco, however, occurred at a ceremony in Old Parliament House on 27 May 2007, Their Spirit Still Shines, which was held to mark the fortieth anniversary of the 1967 referendum and particularly the achievements of those who campaigned for it.

Because of the nature of the event and the audience, comprising campaigners for the referendum and many critics of Howard's policies, it was not easy for him to appeal to those present at that ceremony. This was particularly so in comparison with Rudd, who used the occasion to announce his commitment to saying sorry, in order to make 'new beginnings possible' ${ }^{58}$ What Howard did, apart from an initial gesture to 'the power of myth', which he said was central to 'the larger meaning of the referendum', was to claim the referendum meant the opposite of what those who had campaigned for it intended - that is, federal government responsibility for the failure of Indigenous Australians to enjoy the same opportunities as other Australians. ${ }^{59}$ Howard claimed that, in overwhelmingly endorsing the referendum, the Australian people had wanted to end Aborigines' 'alienation from mainstream society'. ${ }^{60} \mathrm{He}$ said 'for indigenous success to shine through sometimes, frankly, it demands less from government and more from indigenous civil society' ${ }^{61}$ The main change from 1967 was to give the Commonwealth authority to make special laws for Aborigines when required. This was meant to ensure Aborigines could access Commonwealth government resources, yet Howard claimed the main responsibility for overcoming Indigenous poverty and community violence rested with Indigenous people themselves. His aim was to deny government responsibility for their exclusion from opportunities in Australian society. He could never convince his audience to change their view of the referendum, but by recalling 'the bipartisan spirit in which it was carried', and by his actions a month later, he created a policy wedge that outlasted his government. ${ }^{62}$

Much analysis of Howard's ad hoc intervention in the Northern Territory has focused on its episodic and hasty origins. ${ }^{63}$ This was clear from the lack of any provision in the 2007 Federal Budget for what became substantial public 
expenditure. ${ }^{64}$ The crisis of family violence in remote Aboriginal communities, to which the intervention was a belated response, had been publicised several years earlier, in 2003, by Aboriginal leaders such as Jackie Huggins and Mick Dodson. ${ }^{65}$ This does not mean, however, that Howard's intervention lacked cunning. It did not achieve a rise in the opinion polls, which, according to Alexander Downer, had been anticipated by the government; ${ }^{66}$ but that was not Howard's only purpose. He was responding to a challenge that Rudd had made at the end of his speech on 27 May. Rudd said political leaders should focus not 'on what we disagree on in this critical area - so central to our national soul - let us instead focus on what we can agree on', as a basis for unity. ${ }^{67}$ Rudd began his speech by noting that Aboriginal people had been entirely excluded when the Commonwealth Parliament first met in Canberra in 1927 and he ended with an affirmation of 'an enduring spirit of reciprocal partnership' ${ }^{68}$ Howard ignored the historical exclusion of Indigenous peoples and rejected the idea of partnership, but he responded to Rudd's practical challenge about forging 'a common program' with his paternalistic intervention. ${ }^{69}$ While in government, Howard could still determine the character of that program.

The most revealing feature of Howard's justification for the intervention was that he did not attempt to place the social problem of child sexual abuse in remote Aboriginal communities in any historical or policy context. Some policies with no connection to stopping child abuse, such as resuming control of Aboriginal land, were justified as a response to a national emergency, which was compared with a natural disaster such as a cyclone. ${ }^{70}$ Thus, the historical responsibility of government policy for the crisis in Aboriginal communities was minimised. ${ }^{71}$ Howard accused the NT Government of a tardy response to the Little Children Are Sacred report by Pat Anderson and Rex Wild, yet he completely ignored its recommendations for action based on consultation with Aboriginal communities. ${ }^{72}$ The day before the intervention was announced, Mick Dodson had summarised the key elements of successful policy projects in Aboriginal communities as being: intense community involvement with local decision making and control of resources, combined with respectful support by non-Indigenous parts of the community ${ }^{73}$ All these elements were disregarded by the top-down nature of the intervention, which abandoned consultation with Indigenous people and ignored relevant statistical and historical research. ${ }^{74}$ Howard asserted that the intervention would be non-discriminatory and Rudd was prepared 'to give him the benefit of the doubt' by assuming that the bureaucratic controls applying only to Aborigines could be classified as 'positive measures' ${ }^{75}$ In practice, the intervention was inherently discriminatory, and no attempt was made by either Howard or Rudd to explain how measures that reduced Aboriginal autonomy could benefit Aborigines. 
There is a deeper reason why the paternalistic intervention in the Northern Territory reflects a use of history that constrains rather than enables effective public policy in Aboriginal affairs. This relates to the legal debate about whether the 1967 referendum altered the terms of the constitution so that racially discriminatory laws were no longer valid in Australia. That was the aim of those who campaigned for that referendum and most probably the view of the overwhelming majority of electors who supported it. It is the opinion of Michael Kirby, though not a majority opinion of his former fellow High Court judges. His reasoning is that after the referendum it is now ambiguous as to whether the 'race power' authorises laws that discriminate against rather than for the benefit of people of any race, so the issue must be resolved according to Australia's international treaty obligations, which clearly forbid detrimental discrimination. ${ }^{76}$ Those obligations are inconsistent with paternalism and the racially discriminatory legislation underlying the intervention. A real partnership with Indigenous peoples requires that the 'race power' must be only beneficial, so that any law that affects only Indigenous people is negotiated together with their representatives, not imposed against their will. Howard, however, used a distorted view of the referendum to justify changes that amounted to a return to assimilation. The intervention was defended with vague rhetoric about 'breaking from the past', but there was little discussion of the causes of past policy failures or how the changes proposed would help to reduce child abuse. Such deliberate ignoring of past policies constrains rather than enables effective policy formulation. This was hardly a novel approach to Indigenous policy. It had been tried previously in New Zealand by a conservative party that, like Howard's, was languishing badly in the opinion polls.

\section{The mythology of 'nationhood' in New Zealand}

On 27 January 2004, the recently elected leader of the opposition National Party in New Zealand delivered a speech titled 'Nationhood' to a Rotary Club in the affluent suburb of Orewa, north of Auckland. Don Brash had been party leader for three months but had received no bounce in the opinion polls and National's party support was low, at 29 per cent, not much more than its disastrous vote of 21 per cent in the 2002 election. ${ }^{77}$ The tactic used by Brash to change this situation was to manipulate fears experienced by conservative and older pakeha (white) voters who were disturbed by the growing cultural prominence of Maori in New Zealand society and by the belated recognition of the Indigenous rights affirmed in the Treaty of Waitangi. ${ }^{78}$ The speech occurred soon after Helen Clark's Labour Government declared it would overrule a decision by the Court of Appeal to recognise that Maori ownership of the foreshore and seabed could potentially remain in areas without freehold title. ${ }^{79}$ There was a dramatic response in opinion polls to Brash's speech, with a rise of 18 per cent in National Party support, and higher increases for certain groups, such as 29 per cent for 
retirees. ${ }^{80}$ Tariana Turia, one of the founders of the Maori Party who resigned from Labour to protest against its rejection of the Court of Appeal decision, compared Brash's Orewa speech with the anti-refugee strategy of electoral salvation used by Howard during the Tampa crisis, in which one group of vulnerable people was 'cynically set up to be feared' ${ }^{81}$ The difference was that Howard used the power of incumbency to create uncertainty and division, while Brash achieved a similar result operating from a position of weakness in opposition.

Brash sparked the change in his party's political fortunes by focusing on a very simple idea, and reinforcing it through a very selective representation of history. The simple idea was to proclaim that 'the essential notion of one rule for all in a single nation state' requires 'one standard of citizenship', not different rights for different groups of people. ${ }^{82}$ He conflated equality before the law with a uniform New Zealand identity, encapsulated in a particular mistranslation of words spoken in Maori to Maori chiefs by the English emissary William Hobson at Waitangi during the treaty signing in 1840: 'we are one people.' A culturally informed understanding, however, is that a better translation of the words 'he iwi tahi tatou' is to say 'we two peoples together make a nation'. ${ }^{83}$

Brash relied on a widespread reluctance among pakeha to accept that New Zealand was a bicultural nation, a feeling he manipulated by implying that Maori were getting more than others. As the New Zealand historian Michael King observed, 'Brash actually sent out very carefully constructed coded messages that suggested that National is going to turn back the tide on Maori privileges', without saying what those privileges were. ${ }^{84}$ Given that levels of poverty are greater among Maori than among pakeha, Brash's criticism of the Labour Government for creating a society with 'two standards of citizenship... where the minority has a birthright to the upper hand' is absurd. ${ }^{85}$ It showed clearly, however, 'how emotion, when stimulated, can swamp reason, especially when saliency about race issues is high' ${ }^{86}$ A particular example was the Maori seats in Parliament, which Brash described as an 'anachronism' that he would abolish. ${ }^{87}$ The seats do not give Maori more votes as individuals than other New Zealanders. They are merely a way of organising part of the Maori electorate into distinct seats, which has been important for the development of Maori political influence, although voter turnout in those seats has often been lower than in general electorates. It was accepted in New Zealand politics that the Maori seats would remain as long as Maori wished. By proposing their abolition, Brash made a 'calculated appeal to latent prejudice'. ${ }^{88}$

In creating a false impression of Maori privilege, Brash's distortion of history, and his denigration of the role of the Treaty of Waitangi, was central. Revaluing the treaty as a founding document of New Zealand has been crucial for the pakeha recognition that Maori have legitimate historical grievances against the Crown 
for breaching the terms of the treaty. ${ }^{89}$ Brash did not entirely reject the process of settling those grievances, which previous National politicians had contributed to, but he claimed there could be only 'a gesture at recompense' and 'no more than that'. ${ }^{90}$ He dismissed the common view that 'this 19th century treaty' contains lessons for contemporary New Zealand, asserting that it 'did not create a partnership' but instead 'was the launching pad for the creation of one sovereign nation', in which the pakeha majority had the same rights as Maori. ${ }^{91}$ Brash said the treaty should be seen only as an anachronism, not, as one historian has interpreted it, as a 'modern' and 'tribal' treaty with a substantial 'rationale for Maori autonomy' under Article 2. ${ }^{92}$ According to Brash, even Maori had benefited when the treaty was replaced by 'one standard of citizenship' - that is, assimilation — as the framework for government policy until the 1970s. ${ }^{93} \mathrm{He}$ claimed that social disparities between Maori and pakeha 'are not Treaty issues', just 'social welfare issues' involving individuals rather than groups. ${ }^{94}$ The purpose of Brash's rhetoric, spoken to an affluent pakeha audience, was highlighted towards the end of his speech. When discussing the obligations of citizenship, he said 'we ask Maori to take some responsibility themselves for what is happening in their own communities', as if they had not yet done so. ${ }^{95}$ That was like the message Howard tried to convey during the NT intervention when, like Brash, he rejected a partnership with Indigenous peoples and implied that their poverty was their fault.

While Brash lost the subsequent election, his 'rhetoric of illusion' had a big impact on New Zealand politics and ideas of citizenship. ${ }^{96}$ The Labour Government diluted its support for respecting the principles of the Treaty of Waitangi in public policy, in an effort to counter his attack. ${ }^{97}$ Brash's $^{\prime}$ replacement, John Key, later admitted that Brash's rhetoric was misleading, when seen in the 'daylight' of hindsight. He said 'there's actually a pretty good reason for most of what goes on' in Maori policy, creating a very different impression from the cultural division that Brash had conveyed. ${ }^{98}$ Remarkably, after winning the 2008 election, Key formed a National-led government that was supported by the Maori Party as well as by small right-wing parties. The shift in the National Party's rhetoric was reflected in its formal agreement with the Maori Party. The National Party said it would 'act in accordance with' the Treaty of Waitangi and 'not seek to remove the Maori seats without the consent of the Maori people'. ${ }^{99}$ It seems that New Zealand has turned significantly away from Brash's divisive rhetoric.

This does not mean that Brash's rhetoric had no lasting impact, because it had already substantially influenced the Labour Government's policies after the Orewa speech. The extent of that influence was seen in the government's response to international criticism of policies that discriminated against Maori, such as over their historic rights to the foreshore and seabed. In 2005, the UN Special 
Rapporteur on Indigenous rights and basic freedoms, Rodolfo Stavenhagen, visited New Zealand at the government's invitation. In 2006, he released a report in which he dismissed talk of Maori privilege as nonsense and called for recognition of Maori 'collective citizenship', as expressed in the Treaty of Waitangi. ${ }^{100}$ Stavenhagen's report was met with what one editorial called 'defensive resentment' from both major parties. ${ }^{101}$ Such an attitude contributed to New Zealand's rejection in 2007 of the Declaration on the Rights of Indigenous Peoples, when it was approved by the UN General Assembly. Only three other states joined New Zealand in opposing this declaration, which had been subject to significant dilution in order to get support from most other states. Australia was another recalcitrant state, together with Canada and the United States. ${ }^{102}$ All these states share, to varying degrees, an inability to deal adequately with the unfinished business of achieving substantial Indigenous citizenship, understood as a substantive entitlement to real equality of opportunity, not just as a position of formal equality.

\section{Conclusion: the politics of history in comparative perspective}

In Australia and New Zealand, it is certainly true that 'productive learning from history does not come easily' for politicians dealing with Indigenous policy. ${ }^{103}$ One reason for this has been the use by politicians not of analogical filters to understand problems in a proper historical and comparative perspective, but of history merely to justify existing policy. The idea of a partnership with Indigenous peoples, which was central to the apology delivered by Rudd in February 2008, represented a new approach, in that Rudd used history insightfully in his speech, including a reference to the unfulfilled spirit of the 1967 referendum' ${ }^{104}$ He has yet to facilitate such a partnership by creating a formal process of dialogue, as proposed by Pat Dodson. 105

There are various reasons for this. One is Rudd's style as a 'strong leader', more adept at controlling others than at cooperating with them. ${ }^{106}$ That style, however, does not explain the contradiction between his promotion of partnership with Indigenous peoples and his continuation of paternalistic controls in the Northern Territory. As a political exercise in 'crisis exploitation', Howard's intervention was only 'partially successful' because of criticism of his motives and scepticism about the impact of those controls. ${ }^{107}$ There was no rise in support for Howard measured by opinion polls, but he got Rudd to follow a set of largely bureaucratic measures that was not linked to any partnership. Rudd still followed most of Howard's program despite surpassing him so clearly with the apology. This was seen in the slowness with which the new government reviewed the NT intervention. When challenged about the intervention on a $\mathrm{TV}$ forum after being in office for six months, Rudd twice referred to 'the government' of his predecessor in the present tense, even when saying how his 
policy differed from Howard's. Significantly, Rudd mentioned the suspension of the Racial Discrimination Act as a point of difference, but he was unable to say when that suspension, on which Howard's intervention was based, would end. ${ }^{108}$ Almost a year later, in March 2009, Aboriginal people successfully took a complaint against Australia's racial discrimination to the UN Committee for the Elimination of Racial Discrimination. The committee called on the Australian Government to reinstate the act and to reform its policy in direct consultation with Aboriginal communities and individuals affected by the intervention. ${ }^{109}$ The impression that this created was of a government that had been 'slow to act' and that was moving to meet Australia's international obligations reluctantly as a result of international pressure. ${ }^{110}$

What conclusions can be drawn about uses of history by politicians in Australia and New Zealand to justify policies in Indigenous affairs? The central similarity between Howard's intervention and Brash's appeal to pakeha prejudice derived from the claim that Indigenous success demanded less from government and more from Indigenous people themselves. The latter expectation is desirable in itself, but the Orewa episode shows it can be used as an excuse for diminished government responsibility for Indigenous citizenship, understood as access to substantive equality. Brash used a simplistic misrepresentation of New Zealand's past to support policies designed to promote not real equality, but nostalgia for an era that had supposedly been marked by cultural homogeneity. He attempted to diminish Maori concerns, by ignoring the Treaty of Waitangi and by acting more unilaterally, like governments in Australia have often done on Aboriginal issues. The results of such an approach are evident in the huge backlog of under-funded housing, health and education services in the Northern Territory that the intervention has revealed, including the discriminatory lack of provision of many basic services, such as education, to Aboriginal people.

Howard and Brash ultimately suffered political defeats, but the legacies of their constraining uses of history to justify unilateral policies regarding Indigenous peoples remain. They both used the rhetoric of formal equality to deny the need to deal with the unfinished business of Indigenous citizenship. Although their narrow approach to historical understanding has been put aside, it has not yet been effectively transcended in either country. Comparing Howard's constraining use of history with Brash's reveals two things.

First, if a political use of history succeeds as an exercise in crisis exploitation, its impact should be assessed in terms of its effect on a broader policy agenda, not by the chief political actor's immediate fate. When an old leader departs the scene, his rhetoric might be decisively rejected, as with Rudd's apology to the Stolen Generations and Key's post-election affirmation of National's support for the relevance of the Treaty of Waitangi. This does not mean, however, that the new approach to history has already informed relevant policy making in 
Indigenous affairs. For that to occur, a critical assessment is needed of the reasons for past policy failures.

Second, the similarities between Australia and New Zealand are arguably as important as the differences, particularly in view of the struggles in New Zealand to turn government declarations of 'partnership' into a real 'association of equals'. ${ }^{111}$ One year after Australia's belated apology to Indigenous peoples, the dominant feeling remains one of a potential rather than a real partnership. Australians who want the Rudd Government to honour its commitment to a real partnership with Indigenous peoples by creating a treaty can learn from the recent history of New Zealand. Meanwhile, the lesson for New Zealanders from Australia's apology to the Stolen Generations is that, without an enduring bicultural partnership, great rhetoric alone cannot transcend the legacies of assimilation. While the challenge of biculturalism is more familiar to New Zealanders, the Orewa episode reveals the large political obstacles to creating a genuine partnership with Maori. Australians and New Zealanders face similar challenges of achieving substantive equality by creating partnerships with Indigenous peoples. Resolving this unfinished business of Indigenous citizenship will be assisted by understanding the history of past policy failures in a comparative light.

\section{Endnotes}

1 New Zealand Lawyer, 22 January 2007, p. 1.

2 Kirby, Michael 2002, 'The unfinished trans-Tasman business', Commonwealth Law Bulletin, vol. 28, no. 2, pp. 1083-4, 1088, 1090.

3 For example, Evans, Chris 2006, The Labor approach to Indigenous affairs, Speech by the Shadow Minister for Indigenous Affairs to Progressive Branch Alliance, Perth, 26 September 2006, p. 3, $<$ http://eherald.alp.org.au/download/now/evans_indigenous_affairs.pdf>

4 For the historical lack of a fair go, see Buckley, Ken and Wheelwright, Ted 1988, No Paradise for Workers: Capitalism and the common people in Australia 1788-1914, Oxford University Press, Melbourne. 5 Annan, Kofi 1997, Renewing the United Nations: A programme for reform, Report to the fifty-first session of UN General Assembly, New York, p. 10.

6 Brändström, Annika, Bynander, Fredrik and 't Hart, Paul 2004, 'Governing by looking back: historical analogies and crisis management', Public Administration, vol. 82, no. 1, pp. 194-5.

7 For a summary of different analogical uses of history, see ibid., p. 207.

8 Lebow, Richard Ned and Gross Stein, Janice 1994, We All Lost the Cold War, Princeton University Press, Princeton, NJ, pp. 120-3; May, Ernest R. and Zelikow, Philip D. (eds) 1997, The Kennedy Tapes: Inside the White House during the Cuban missile crisis, Harvard University Press, Cambridge, Mass., pp. 121, 149.

9 Lebow and Stein, We All Lost the Cold War, p. 124, point out: 'The Kennedy inner circle was so worried about the consequences of publicity that they rewrote history.'

10 Brändström et al., 'Governing by looking back', pp. 195, 207.

11 Ibid., pp. 195, 207.

12 MccGwire, Michael 2006, 'Nuclear deterrence', International Affairs, vol. 82, no. 4, pp. 773-6.

13 Gunstone, Andrew 2007, Unfinished Business: The Australian formal reconciliation process, Australian Scholarly Publishing, Melbourne, pp. 89, 290.

14 Dodson, Patrick 2007, 'Whatever happened to reconciliation?', in Jon Altman and Melinda Hinkson (eds), Coercive Reconciliation, Arena, Melbourne, pp. 27-8. 


\section{Does History Matter?}

15 Baubock, Rainer 1994, Transnational Citizenship: Membership and rights in international migration, Edward Elgar, Aldershot, p. 23.

16 Pearson, Noel 2000, Our Right to Take Responsibility, Noel Pearson and Associates, Cairns, pp. 13-14, 30, 99. Pearson's view is supported by Marcia Langton (2008, 'Trapped in the Aboriginal reality show', Griffith Review, no. 19, pp. 158-9). See also Walter, James and Macleod, Margaret 2002, The Citizens' Bargain: A documentary history of Australian views since 1890, UNSW Press, Sydney, pp. 10, 12-13.

17 Megan Davis, 'Arguing over Indigenous rights: Australia and the United Nations', in Altman and Hinkson, Coercive Reconciliation, pp. 104-5.

18 Pearson, David 2004, 'Rethinking citizenship in Aotearoa/New Zealand', in Paul Spoonley, Cluny Macpherson and David Pearson (eds), Tangata Tangata: The changing ethnic contours of New Zealand, Dunmore Press, Southbank, pp. 294-5, 311.

19 Castles, Stephen 2005, 'Nation and empire: hierarchies of citizenship in the new global order', International Politics, vol. 42, no. 2, p. 205.

20 Ibid., pp. 205, 206-7.

21 McHugh, Paul 2004, Aboriginal Societies and the Common Law, Oxford University Press, Oxford, p. 609.

22 Baubock, Transnational Citizenship, pp. 278, 298.

23 Castles, 'Nation and empire', pp. 205, 219-20.

24 Quoted in Chesterman, John and Galligan, Brian 1997, Citizens Without Rights: Aborigines and Australian citizenship, Cambridge University Press, Melbourne, p. 218.

25 Moreton-Robinson, Aileen 2007, 'Writing off Indigenous sovereignty: the discourse of security and patriarchal white sovereignty', in Aileen Moreton-Robinson (ed.), Sovereign Subjects: Indigenous sovereignty matters, Allen \& Unwin, Sydney, pp. 98-9.

26 Rubenstein, Kim 2000, 'Citizenship and the centenary: inclusion and exclusion in 20th century Australia', Melbourne University Law Review, vol. 24, no. 3, pp. 577-8.

27 Moreton-Robinson, 'Writing off Indigenous sovereignty', p. 99; Darryl Cronin, 'Welfare dependency and mutual obligation: negating Indigenous sovereignty', in Moreton-Robinson, Sovereign Subjects, pp. 187-8.

28 Walter and Macleod, The Citizens' Bargain, p. 1.

29 Wendy Brady, 'That sovereign being: history matters', in Moreton-Robinson, Sovereign Subjects, p. 149.

30 Beckett, Jeremy 1998, 'Aboriginality, citizenship and nation-state', Social Analysis, no. 24, p. 10.

31 In a submission to a case involving Alec Kruger, a member of the Stolen Generations, the Australian section of the International Commission of Jurists noted that the 'total control' that the State had over the lives of Aborigines such as Kruger was 'the hallmark of totalitarianism and is the antithesis of representative government'. See Buti, Tony (ed.) 1996, After the Removal: A submission by the Aboriginal Legal Service of Western Australia (Inc) to the National Inquiry into Separation of Aboriginal and Torres Strait Islander Children from their Families, Aboriginal Legal Service, Perth, Appendix A, p. 418. For the impact of such control on one family across generations, see Beresford, Quentin 2006, Rob Riley: An Aboriginal leader's quest for justice, Aboriginal Studies Press, Canberra.

32 For the development of Neville's views, see Beresford, Rob Riley, pp. 13-23.

33 Speech by A. O. Neville to initial conference of Commonwealth and State Aboriginal Authorities, Parliament House, Canberra, April 1937, reprinted in 1995 as Appendix A in Telling Our Story: A report by the Aboriginal Legal Service of Western Australia (Inc) on the removal of Aboriginal children from their families in Western Australia, Aboriginal Legal Service, Perth, p. 208.

34 Haebich, Anna 2000, Broken Circles: Fragmenting Indigenous families 1800-2000, Fremantle Arts Centre Press, Fremantle, pp. 162-4.

35 Moreton-Robinson, Aileen 2001, Treaty talk: past, present, future, Ngunnawal Lecture, University of Canberra, p. 7.

36 Apology to Australia's Indigenous Peoples, Commonwealth Parliamentary Debates [hereafter CPD], Representatives, 13 February 2008, p. 167.

37 Kevin Rudd, CPD, Representatives, 13 February 2008, p. 169.

$38 C P D$, Representatives, 13 February 2008, p. 172. 
39 Sam Watson, interviewed on 'Saying sorry', Message Stick, ABC TV, 25 May 2008. He was sceptical because of a concern that there would be no follow up to the apology after the opening of the new parliamentary session.

40 CPD, Representatives, 13 February 2008, p. 167.

41 Ibid., p. 167.

42 Nobles, Melissa 2008, The Politics of Official Apologies, Cambridge University Press, New York, p. x. Justice Kirby affirmed such a change in the Blue Mud Bay native title case decided in July 2008, when he said the apology was now a crucial 'element of the social context' in which native title must be understood and applied. Northern Territory vs Arnhem Land Aboriginal Land Trust [2008], 82 ALJR 1099 at 1115 [71] per Kirby J.

43 CPD, Representatives, 13 February 2008, p. 171.

44 Ibid., p. 172.

45 Ibid., p. 169.

46 For the importance of compensation and the relevance of comparisons with Canada, see National Inquiry into the Separation of Aboriginal and Torres Strait Islander Children from their Families 1997, Bringing Them Home: Report of the National Inquiry into the Separation of Aboriginal and Torres Strait Islander Children from their Families, Human Rights and Equal Opportunity Commission, Sydney, pp. 278-9, 302-13, 573-7.

47 CPD, Representatives, 13 February 2008, p. 172.

48 Ibid., p. 171.

49 Dodson, Pat 2007, A call for a new national dialogue between Indigenous and non-Indigenous Australians, La Trobe University Centre for Dialogue lecture, Brunswick, 10 October 2007 (excerpted in Connections: Newsletter of the Centre for Dialogue, vol. 2, p. 2).

50 Rudd, CPD, Representatives, 13 February 2008, p. 172. The main reason for the failure to establish this commission was the Opposition's insistence on involving the former Minister for Aboriginal Affairs, Mal Brough, who lost his seat at the 2007 election.

51 Ibid., p. 172.

52 See Pitty, Roderic 2008, 'Faith Bandler: campaigning for racial equality', in G. Stokes, R. Pitty and G. Smith (eds), Global Citizens: Australian activists for change, Cambridge University Press, Melbourne, pp. 35-9.

53 'Dodson wants intervention review brought forward', $A B C$ News, 2 February 2008, <www.abc.net.au/news/stories/2008/02/02/2152845.htm>; Calma, Tom 2007, Social Justice Report 2007, ch. 3, part 4, <www.hreoc.gov.au/social_justice/sj_report/sjreport07/chap3.html>

54 Calma, Tom 2008, Speech, Sydney, 31 March 2008, p. 4, $<$ www.hreoc.gov.au/pdf/social_justice/speech/protecting_indigenous_children.pdf $>$ 55 Ibid., p. 4.

56 Behrendt, Larissa 2008, What follows sorry, Speech, University of Technology, Sydney, 19 March 2008 , p. 6, <www.uts.edu.au/new/speaks/2008/March/resources/1903-transcript.htm>

57 Rudd, CPD, Representatives, 13 February 2008, p. 171.

58 Rudd, Kevin 2007, On the future of reconciliation, Speech at the Fortieth Anniversary of the 1967 Referendum, Canberra, 27 May 2007, p. 2, <www.reconciliation.org.au/downloads/156/Kevin_Rudd_Their_Spirit_Still_Shines.pdf>

59 Howard, John 2007, Their spirit still shines, Speech at the Fortieth Anniversary of the 1967

Referendum, Canberra, 27 May 2007, p. 1,

$<$ www.reconciliation.org.au/downloads/156/John_Howard_Their_Spirit_Still_Shines.pdf $>$

60 Ibid., p. 2.

61 Ibid., p. 3 [emphasis added].

62 Ibid., p. 1.

63 Toohey, Paul 2008, 'Last drinks: the impact of the Northern Territory intervention', Quarterly Essay, no. 30 , p. 48

64 The last federal budget brought down by Howard and his Treasurer, Peter Costello, in May 2007, actually had the lowest spending on Indigenous affairs as a percentage of Federal Government revenue (1.18 per cent) of any of the 12 budgets they had delivered since 1996. This percentage was lower than in any year since 1990 (National Indigenous Times, 29 May 2008, p. 16). 


\section{Does History Matter?}

65 Statement by Reconciliation Australia in response to the national emergency measures to protect Aboriginal children, 21 June 2007, <www.reconciliation.org.au/downloads/157/Family_Violence.pdf>

66 Behrendt (What follows sorry, p. 3), referring to Downer's comments on ABC TV's Insiders on 25 November 2007.

67 Rudd, On the future of reconciliation, p. 4.

68 Ibid., pp. 1, 4.

69 Ibid., p. 4.

70 Howard, John 2007, Press conference transcript, 21 June 2007, p. 6, $<$ www.eniar.org/news/JohnHowardPM.html>

71 On this responsibility, see Dillon, Michael and Westbury, Neil 2007, Beyond Humbug: Transforming government engagement with Indigenous Australia, Seaview, Adelaide, pp. 196-7.

72 Commentary by Ian Anderson comparing those recommendations with the intervention as originally formulated by the Howard Government, Australian Policy Online, 29 June 2007,

<www.apo.org.au/webboard/results.chtml?filename_num=161613>

73 Dodson, Mick 2007, Whatever happened to reconciliation?, Public lecture, 20 June 2007, p. 4, $<$ www.reconciliation.org.au/i-cms.isp?page $=110>$

74 Altman, J. C. 2007, The Howard Government's Northern Territory intervention: are neo-paternalism and Indigenous development compatible?, Address to Australian Institute of Aboriginal and Torres Strait Islander Studies conference, Canberra, 7 November 2007, pp. 9, 13,

$<$ www.anu.edu.au/caepr/Publications/topical/Altman_AIATSIS.pdf $>$

75 Howard, Press conference transcript, 21 June 2007, p. 6; Rudd, Interview with Laurie Oakes, Sunday, Channel 9, 24 June 2007, p. 2,

$<$ http://sunday.ninemsn.com.au/sunday/political_transcripts/article_2236.asp>

76 Roderic Pitty, 'Michael Kirby: speaking for human rights', in Stokes et al., Global Citizens, pp. 168-9. Justice Kirby applied his reasoning to a case concerning the discriminatory nature of the Commonwealth's NT emergency response legislation in Wurridjal vs The Commonwealth of Australia [2009], HCA 2

[2 February 2009], paragraphs 214-15, 264-73, <www.austlii.edu.au/au/cases/cth/HCA/2009/2.html>

77 Johansson, Jon 2004, 'Orewa and the rhetoric of illusion', Political Science, vol. 56, no. 2, pp. 115-6.

78 Ibid., p. 123; James, Colin 2004, The political context of the Treaty of Waitangi and human rights, Speech at Human Rights Commission symposium, Wanganui, 20 July 2004, pp. 2, 3,

<www.colinjames.co.nz/speeches_briefings/Hn_Rights_Comm_04Jul20.htm>

79 Hongston, Ken 2006, 'Foreshore and seabed', in Malcolm Mulholland (ed.), State of the Maori Nation: Twenty-first century issues in Aotearoa, Reed, Auckland, p. 111.

80 Johansson, 'Orewa and the rhetoric of illusion', p. 124. The attitudes typical of many pakeha retirees were expressed by middle-aged and some younger pakeha as well. For examples, see McCreanor, Tim 2005, 'Talking pakeha identities', in James Liu et al. (eds), New Zealand Identities: Departures and destinations, Victoria University Press, Wellington, pp. 61-4.

81 Tariana Turia, South Taranaki Star, 29 November 2007, $<$ www.maoriparty.com/index.php?option=com_content\&task=view\&id=1462\&Itemid=82>

82 Brash, Don 2004, Nationhood, Address to Orewa Rotary Club, 27 January 2004, p. 3,

$<$ www.national.org.nz/files/OrewaRotaryClub_27Jan.pdf >

83 Williams, David 2004, 'Myths, national origins, common law and the Waitangi Tribunal', Murdoch University Electronic Journal of Law, vol. 11, no. 4, p. 10,

$<$ www.murdoch.edu.au/elaw/issues/v1ln4/williams114_text.html>

84 King, Michael 2004, Interview with Kim Hill, Face to Face, NZ TV One, 3 March 2004, p. 2,

$<$ http://www.anewnz.org.nz/paper_comments.asp?paperid $=30>$

85 Brash, Nationhood, pp. 2-3.

86 Johansson, 'Orewa and the rhetoric of illusion', pp. 122, 125.

87 Brash, Nationhood, p. 14.

88 Durie, Mason 2005, Nga Tai Matatu: Tides of Maori endurance, Oxford University Press, Melbourne, p. 223.

89 Consedine, Robert and Consedine, Joanna 2005, Healing Our History: The challenge of the Treaty of Waitangi, Updated edn, Penguin, Auckland; Snedden, Patrick 2005, Pakeha and the Treaty: Why it's our treaty too, Random House, Auckland.

90 Brash, Nationhood, p. 5. 
91 Ibid., pp. 8, 13.

92 Belgrave, Michael 2005, Historical Frictions: Maori claims and reinvented histories, Auckland University Press, Auckland, pp. 84, 85.

93 Brash, Nationhood, p. 5.

94 Ibid., p. 14.

95 Ibid., p. 14.

96 Johansson, 'Orewa and the rhetoric of illusion', p. 128; David Pearson, 'Citizenship, identity and belonging: addressing the mythologies of the unitary nation state in Aotearoa/New Zealand', in Liu et al., New Zealand Identities, pp. 21, 33; O'Sullivan, Dominic 2008, 'The Treaty of Waitangi in New Zealand politics', Australian Journal of Political Science, vol. 43, no. 2, p. 324.

97 Vowles, J. 2005, 'New Zealand', European Journal of Political Research, vol. 44, nos 7-8, p. 1137; Durie, Nga Tai Matatu, pp. 223-4.

98 John Key, interviewed by Simon Wilson, Auckland Metro Live, 22 January 2008, pp. 3-4, $<$ www.grownups.co.nz/read/lifestyle/people/leaders-interview-john-key $>$

99 Relationship and Confidence and Supply Agreement between the National Party and the Maori Party, 16 November 2008, pp. 1, 2, <www.parliament.nz/NR/rdonlyres/ 22CACF7A-2530-45E6-9569-518E53CF0056/94925/NationalMaori_Party_agreement20092.pdf>

100 Stavenhagen, Rodolfo 2006, Mission to New Zealand, Report of the Special Rapporteur on the Situation of Human Rights and Fundamental Freedoms of Indigenous People, UN Doc E/CN.4/2006/78/Add.3, 10 March 2006, pp. 9, 12, <www.converge.org.nz/pma/srnzmarch06.pdf> 101 'UN report worthy of discussion', New Zealand Herald, 6 April 2006.

102 Daes, Erica-Irene 2008, 'An overview of the history of Indigenous peoples: self-determination and the United Nations', Cambridge Review of International Affairs, vol. 21, no. 1, p. 22. Australia announced on 3 April 2009 that it now endorsed the Declaration on the Rights of Indigenous Peoples.

103 Brändström et al., 'Governing by looking back', p. 208.

104 Rudd, CPD, Representatives, 13 February 2008, p. 172.

105 Dodson, Patrick 2008, 'After the apology', Arena Magazine, vol. 94, pp. 20-3; Calma, Tom 2009, 'Laying the foundations', Koori Mail, 11 March 2009.

106 't Hart, Paul 2008, The Limits of Crisis Exploitation: The NT intervention as a reform boomerang, p. 10, <http://polsc.anu.edu.au/staff/hart/pubs/NTinterventionARENAversionMarch08.pdf>, citing Walter, J. and Strangio, p. 2007, No, Prime Minister: Reclaiming politics from leaders, UNSW Press, Sydney.

107 't Hart, Paul 2007, 'Crisis exploitation: reflections on the "national emergency" in Australia's Northern Territory', Dialogue, vol. 26, no. 3, pp. 53-5. Langton ('Trapped', p. 158) accepts that 'there are critics with a genuine concern about the extent and implementation of the intervention'.

108 Kevin Rudd, interview on $Q$ \& A, ABC TV, 22 May 2008, approximately 42 minutes into program. In October 2008, the Rudd Government rejected advice from its official Review Board report into the NT intervention, which had recommended an 'immediate change' of policy to conform with the Racial Discrimination Act (Report of the Northern Territory Emergency Response Review Board, Commonwealth of Australia, October 2008, p. 47, <www.nterreview.gov.au/docs/report_nter_review/default.htm>).

109 Letter from Fatimata-Binta Victoire Dah, Chairperson, Committee for the Elimination of Racial Discrimination, to Australia's Ambassador in Geneva, 13 March 2009, annexed to a statement on 18 March 2009 by Les Malezer,

<www.indigenousportal.com/index.php/News/-Australia-promises-to-end-racial-discrimination.html> 110 Williams, George 2009, 'Rudd must act if race complaint upheld', Sydney Morning Herald, 10 February 2009.

111 Durie, Mason 1994, Whaiora: Maori health development, Oxford University Press, Auckland, p. 87. For struggles in New Zealand, see Belgrave, Michael, Kawharu, Merata and Williams, David (eds) 2005, Waitangi Revisited: Perspectives on the Treaty of Waitangi, Oxford University Press, Auckland. For Australia, see Read, Peter, Meyers, Gary and Reece, Bob (eds), What Good Condition? Reflections on an Australian Aboriginal treaty 1986-2006, Aboriginal History Monograph 13, ANU E Press, Canberra. 